\title{
THE MINERALOGICAL MAGAZINE
}

\author{
AND \\ JOURNAL OF \\ THE MINERALOGICAL SOCIETY
}

\begin{tabular}{lll}
\hline \hline No. 234 & September, 1956 & Vol. XXXI \\
\hline
\end{tabular}

\section{Frederick Noel Ashcroft.}

By W. Campbell Smith.

$\mathrm{F}$ REDERICK NOEL ASHCROFT was Treasurer of the Society from 1924 to 1942, President 1942-45, Foreign Secretary from 1947, and one of the Society's two Trustees from 1911 until his death. This occurred quite suddenly at his home in London on 4 April 1949. He would have been 71 on the 28th of August of that year. Most of the details of his life and work are recorded in an obituary notice in the 'Quarterly Journal of the Geological Society' (1950, vol. 105, pp. lxixlxxii), but it seems fitting that his work should receive some special mention in the pages of our own Journal, for in his long service he did much for the Society by his careful management of its affairs, and by his mineral collecting and his generous gifts to the British Museum he made a substantial contribution to our Science.

The membership when Asheroft became Treasurer was only 180 and it had increased only by 87 at the beginning of the war in 1939 . The annual income at that time was no more than $£ 750$, so the keeping of the accounts was a small matter to one of Ashcroft's calibre. However, he took his duties very seriously and any member who had not signed a banker's order or become a Life Member was certain to receive a reminder that his subscription was due, addressed in Ashcroft's own hand and posted on New Year's Eve! The bills for printing the Magazine and the statements of sales were always scrutinized with the greatest care, and he kept a close check on the stock of back numbers. In this connexion he made quite a hobby of buying up runs of the Magazine whenever he could, and he used these to make up sets to meet the needs of mineralogists and libraries at home and abroad. In many unobtrusive ways he helped the Society financially, and much of the expense he incurred in the office work on the Society's accounts he bore himself without ever letting the extent 
of his expenditure be known. In its Honorary Treasurer as well as in its Honorary Editor the Society was undoubtedly remarkably well served.

As a mineralogist Ashcroft did little detailed research and published little, but he was a very keen collector and indefatigable in his labelling and cataloguing, and he has left in the Department of Mineralogy of the British Museum (Natural History) three collections each of which in its own field is unrivalled for fine quality of specimens and for wealth of detail as to locality and mineral associations.

Ashcroft's mineral collecting began while he was at Oxford where he had entered Magdalen College from Rugby in 1897. He accompanied [Sir Henry] Miers, then Professor of Mineralogy at Oxford, on excursions with his students to British mineral localities, and in 1901 he joined [Sir] Harold Hartley on a mineral-collecting visit to the Seiser Alpe in the Tyrol.

At first Ashcroft specialized on zeolites and between 1901 and the outbreak of the First World War he had assembled a collection of some 2000 specimens from about 80 localities, chiefly in Europe and America. This collection he presented to the British Museum in 1914, intending to concentrate his own attention on the zeolites of the Tertiary basalts of Northern Ireland of which he had already made a considerable collection. In this work he had already enlisted the interest of two well-known Belfast naturalists, Robert Bell, a geologist and mineralogist, and R. J. Welch, well known at that time for his geological, botanical, and zoological photographs. When Ashcroft's own visits to Ireland became impracticable owing to the outbreak of war Bell continued to visit the working quarries and to collect the zeolites, dispatching specimens from time to time to Ashcroft in London. As a result Ashcroft acquired a remarkably fine collection of specimens from about 90 localities, chiefly in County Antrim. Every available detail was recorded in manuscript catalogues, and photographs by R. J. Welch of the quarries and cliff sections are filed in loose-leaf books.

Ashcroft intended working up the material in this collection himself but this he never had time to do, and under the terms of his will it passed to the British Museum (Natural History) at his death. His only published works on the zeolites were two papers by himself and topographical notes contributed to a paper by G. F. Herbert Smith on chabazite and associated minerals from County Antrim in the 'Mineralogical Magazine' for 1916 .

The largest and best known of Ashcroft's three collections is his collection of Swiss minerals. This he commenced soon after the First World 
War. During yearly visits to Switzerland he came to know all the leading mineralogists and the local mineral collectors. From the collectors, many of them expert Alpine guides, he purchased great numbers of fine specimens, but it was a condition he made that for every specimen he must be able to ascertain the exact locality and if possible to see and examine each locality himself. He insisted that if the paragenesis of the minerals was to be thoroughly studied, it was essential that specimens from neighbouring fissures, even if situated only a few feet apart, must be kept separate.

His principal collecting areas centred about Disentis and Sedrun in the Vorder Rhein Valley and about Andermatt and Amsteg. From the last two places he could reach not only the mineral localities accessible from the Reuss Valley but also those in the St. Gotthard district, in Urseren Thal, Göschenen Thal, and in Maderaner Thal. He was in frequent correspondence with Franz Indergand of Ried by Amsteg and others of the Indergand family in that district and in Göschenen. His most constant correspondents, and the two who seem to have been the most helpful of the local collectors in and around Tavetsch Thal, were Adolf Caveng, the postmaster at Sedrun, and his son Ambrosi. Ashcroft's practice was to send maps to the Indergands and to the Cavengs on which the sites of any finds they made could be marked. In the following summer he would visit the localities himself accompanied by the collectors and would photograph the sites. Prints of these photographs were then used to pin-point the finds more precisely and to record any further finds there might be. For this work he used a half-plate stand camera with a heavy tripod stand. He considered smaller negatives did not give him suitable reproductions for his purpose and the stand needed to be suitable for use on steep, rough ground. With this heavy equipment he travelled considerable distances in the mountains and he went to great trouble to get to positions from which to photograph every accessible site.

Much of the accurate information he obtained about the Swiss minerals and their paragenesis he contributed to 'Die Mineralien der Schweizeralpen' by Niggli, Koenigsberger, and Parker (1940), and 16 plates in that work are reproductions of Ashcroft's photographs. Some others of his photographs appear as plates in Holmes's 'Principles of Physical Geology' (1944).

The whole of the Swiss collection of over 6000 specimens was presented to the British Museum between 1921 and 1938 and the catalogues and the negatives and prints of all his photographs connected with the 
collections have now also passed to the Museum under the terms of his will. He also left in trust a sum of $£ 100$ for the purpose of completing the catalogues of his mineral collections.

Besides these collections Asheroft presented many other specimens to the British Museum: specimens from the Tyrol in 1903; a fine selection purchased from the Walker Collection in 1912; minerals from Wales, Derbyshire, the Lake District, and Cumberland collected on short holidays with his family during the First World War; and a fine series of specimens of minerals from Broken Hill, Rhodesia, partly collected by himself on a visit to the mine during an excursion of the International Geological Congress in 1929 and added to on a separate visit by Mr. D. W. Bishopp, then curator of the Rhodesia Museum.

The value of his contributions to our national collection of minerals is not to be measured by numbers of specimens, but the total is close on ten thousand. Ashcroft's gifts to the Museum far exceed those of any other single benefactor of the Department of Mineralogy up to the present time.

Under his will he left his complete sets of the 'Mineralogical Magazine,' the 'American Mineralogist', and the 'Schweizerische Mineralogische und Petrographische Mitteilungen' to the Society together with the sum of $£ 150$ with the sole proviso that it be not 'used for the purpose of providing any prize or medal or a reward of any sort to individual persons'. Selections of his other mineralogical books were left to the Department of Mineralogy of the British Museum and the Geological Society of London, and others were given to the Department of Geology and Mineralogy at Oxford and to University College, London.

Ashcroft had travelled extensively in France, Germany, Austria, Italy, and Sicily, as well as to South Africa and Rhodesia on the Geological Congress of 1929 and on two holidays with his family to Nova Scotia where the famous zeolites had always an attraction. He had made many friends in many lands among mineralogists and geologists. With the mineral collectors and guides in Switzerland he was on the happiest terms, and a warm welcome awaited him and any members of his family on his arrival in their districts for his annual visit. Robert Bell of Belfast he held in special regard and he kept up a correspondence with him long after they had ceased to collect the Irish zeolites. Letters to Asheroft from Robert Bell and from the Cavengs are full of references to generous and kindly acts such as Asheroft never spoke of but was always doing for his friends.

He married in 1904 Constance Muriel, daughter of J. C. im Thurn, and 
their family life was a very happy one. Ashcroft was justly proud of his sons and daughters and devoted to them, and in later years to his grandchildren. Our portrait (plate VII) shows him with two of his grandsons in the garden of a house in Oxford he occupied during some of the years of the last war.

It is six years now since his passing but his memory is fresh among us. He will not soon be forgotten and his mineral collections will remain always as his memorial. 


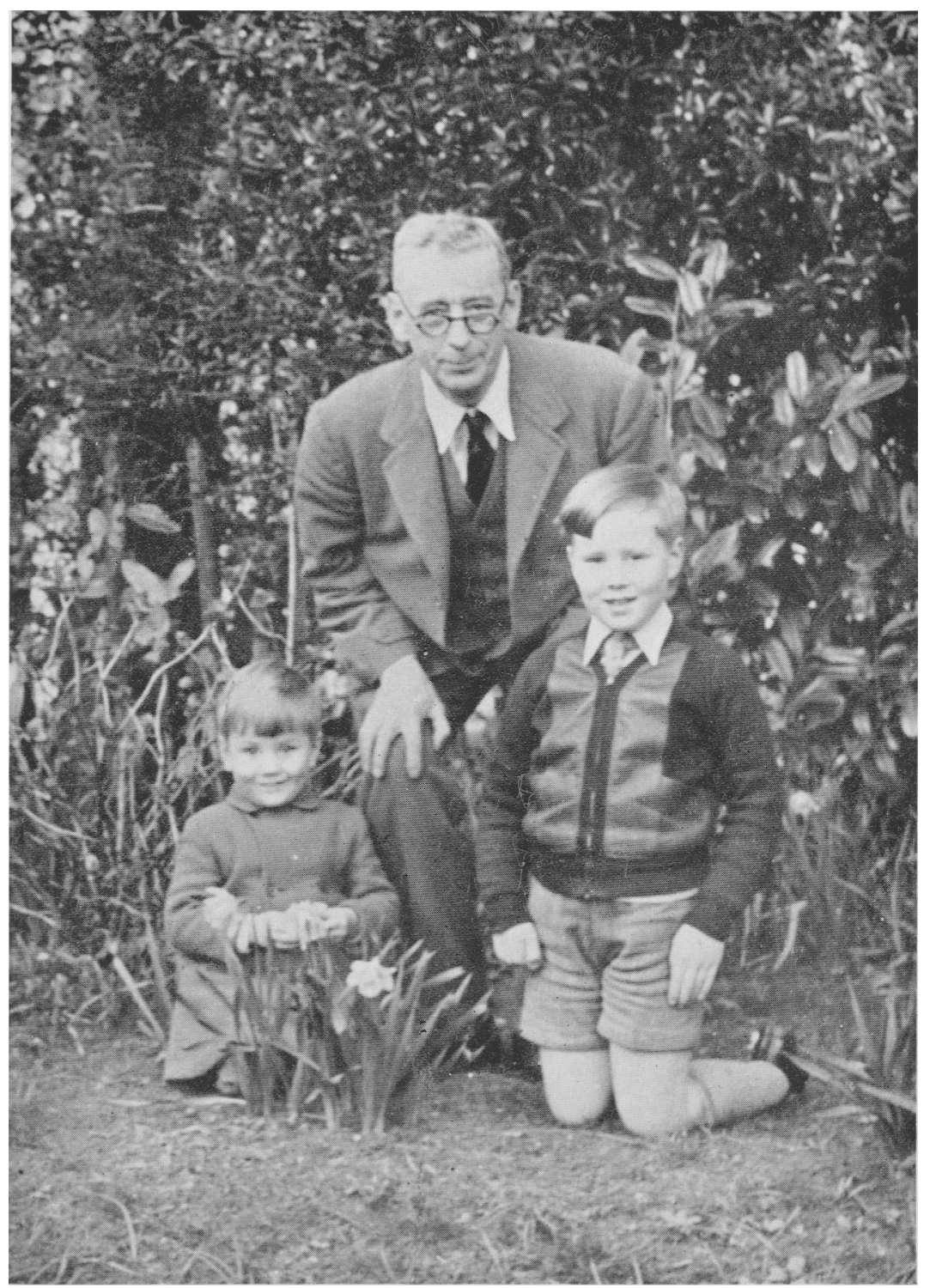

Frederick Noel Ashoroft 